\title{
FUNGSI PERILAKU BIROKRASI DALAM PELAYANAN DI DISTRIK BIAK KOTA KABUPATEN BIAK NUMFOR
}

\author{
Djamil Hasim* \& Amiruddin
}

Program Studi Administrasi Publik, Institut Ilmu Sosial dan Ilmu Politik YAPIS Biak, Indonesia

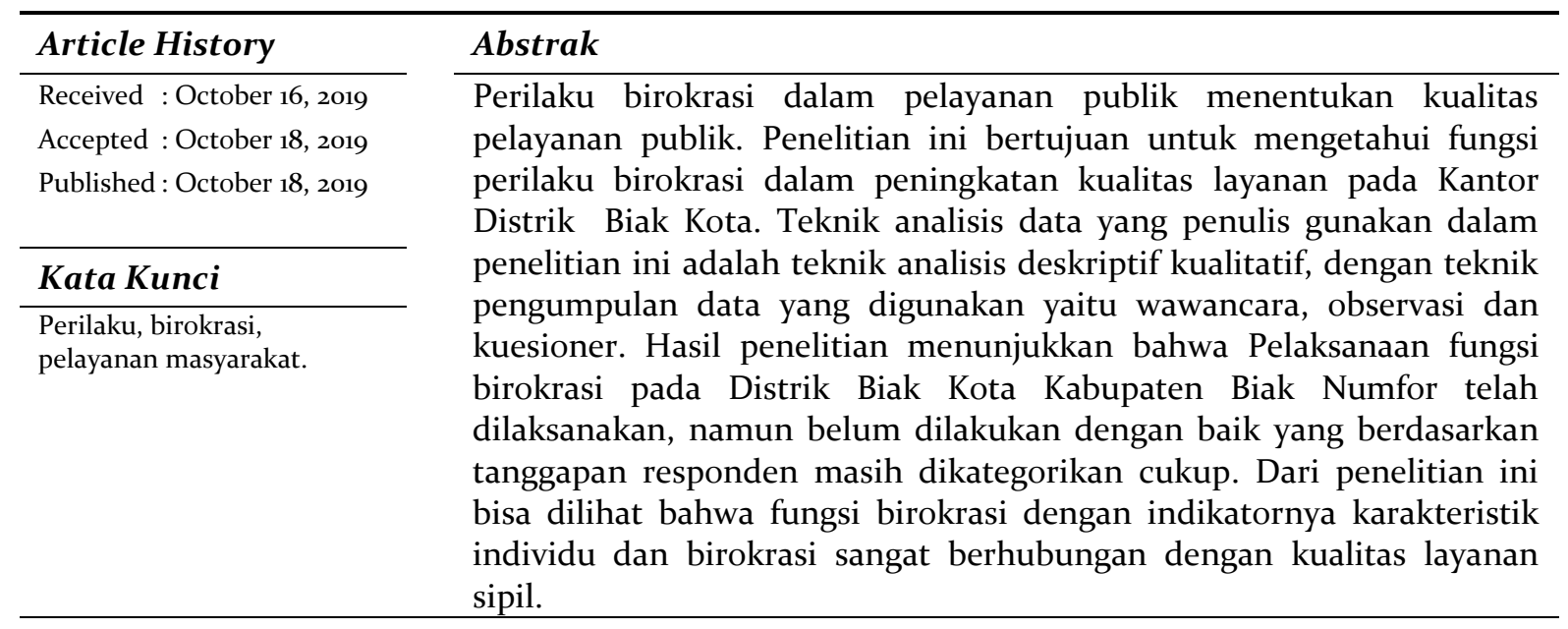

\section{PENDAHULUAN}

Kehadiran organisasi pemerintahan atau birokrasi pada dasarnya bertujuan untuk memelihara dan menjaga ketertiban, agar masyarakat baik pribadi maupun kelompok dapat kehidupan secara normal sesuai prinsip-prinsip kehidupan berbangsa dan bernegara. Sebagai pelayan masyarakat, maka pemerintah harus bersifat antisipatif dan proaktif terhadap semua kebutuhan dan keinginan masyarakat tanpa membedakan suku, ras dan agama. Kenyataan terhadap pelayanan yang selama ini diberikan kepada masyarakat terkesan masih jauh dari harapan dan tujuan keberadaan pemerintah itu sendiri.

Birokrasi di Indonesia, baik di tingkat pusat maupun di tingkat daerah, sepanjang Orde Baru kerap mendapat sorotan dan kritik yang tajam karena perilakunya yang tidak sesuai dengan tugas yang diembannya sebagai pelayan masyarakat, sehingga apabila orang berbicara tentang birokrasi selalu berkonotasi negatif (Sartika, 2013). Dengan berbagai ketidakpuasan masyarakat yang seringkali diterima sebagai wujud dari kondisi pelayanan yang diberikan oleh pemerintah mengindikasikan belum berkualitas gambaran kegiatan yang dilaksanakan pemerintah. Kinerja aparatur yang kurang profesional, bertele-tele, lambat, tidak disiplin merupakan sebagian bentuk gambaran dari berbagi persoalan yang menjadi fenomena, hingga mencitrakan birokrasi pemerintah yang semakin buruk di mata masyarakat.

Perwujudan birokrasi pemerintahan baik dari tingkat pusat bahkan terutama di daerah-daerah yang berorientasi pada pelayanan kepada masyarakat, maka reformasi birokrasi diarahkan secara keseluruhan diarahkan untuk membentuknya agar lebih efisien, efektif dan inovatif, terutama menyediakan pelayanan kepada masyarakat. 
Kebutuhan masyarakat semakin luas dan kompleks harus diimbangi dengan kondisi birokrasi pemerintah yang lebih proaktif dalam menyelaraskan kemampuan yang dimilki dengan kewajiban yang dijalankan. Tercipta penyelenggaraan pemerintahan daerah yang efektif dan efisien tidak akan terlepas dari tingkat adaptifnya aparatur/ pegawai yang dimiliki dengan berbagai perubahan yang ada, teruatama perubahan yang terjadi pada ilmu pengetahuan dan teknologi komunikasi serta informasi.

Berkualitasnya pelayanan yang diberikan kepada masyarakat oleh pemerintah di daerah merupakan bentuk nyata keberhasilan aparaturnya menjalankan semua tugas dan tanggung jawab secara baik. Kondisi akan didapat sangatlah bergantung kepada kepemimpinan masing-masing unit kegiatan pemerintah dalam menata, mengarahkan, mengawasi dan mengevaluasi secara baik setiap pelaksanaan tugas pokok dari bawahannya. Peran seorang pimpinan pada lingkup kegiatan pemerintah dalam berbagai satuan kerja perangkat daerah dalam menjalankan kepemimpinannya akan sangat menentukan kondisi dari organisasi yang dipimpinnya.

Kepemimpinan yang selalu menekankan terhadap aspek keadilan dengan memberikan penghargaan terhadap yang berhasil, sebaliknya hukuman bagi yang melakukan pelanggaran merupakan efek kebijakan untuk memberikan rasa tanggung jawab kepada bawahan secara baik dalam melaskanakan tugas dan pekerjaan yang menjadi kewajibannya. Motivasi kerja bawahan atau pegawai dengan sendiri akan meningakat yang sudah tentu akan bermuara bagi pelaksanaan tugas, pokok, dan fungsinya secara lebih optimal. Lebih lanjut, Menjalankan perilaku birokrasi dalam kedisiplinan juga dituntut setiap aparat untuk memiliki kepatuhan pada pimpinan (Benny Kurniawan Putra Sembiring, Heri Kusmanto, 2016).

Kondisi dalam menciptakan penyelenggaraan pelayanan yang berkualitas kepada masyarakat merupakan fenomena penting untuk dikaji secara lebih mendalam. Seperti yang telah dikemukakan sebelumnya bahwa pegawai memiliki andil yang besar sebagai penyebab dari pelayanan publik yang tidak berkualitas. Eksistensi pegawai dalam memberikan pelayanan kepada masyarakat, secara teoritik dapat dikaji dari berbagai dimensi seperti perilaku, motivasi, efektivitas dan lain sebagainya, namun khusus dalam penelitian ini masalah pelayanan publik dipandang dari sudut kepemimpinan.

Atas dasar berbagai pemikiran tersebut di atas, maka penulis merasa tertarik untuk mengkaji secara lebih mendalam tentang fungsi perilaku birokrasi terhadap kualitas layanan sipil, dengan mengambil lokasi di Kantor Distrik Biak Kota dengan pertimbangan bahwa wilayah pemerintahan ini merupakan wilayah yang beragam penduduknya dan berbagai kompleksitas kebutuhan dan keinginan karena distrik ini berada di jantung kota Biak. Dengan demikian, maka penulis tertarik untuk melakukan suatu penelitian dengan judul: "Fungsi Perilaku Birokrasi dalam Meningkatkan Kualitas Layanan Masyarakat pada Distrik Biak Kota Kabupaten Biak Numfor".

\section{METODE DAN FOKUS PENELITIAN}

\section{Lokasi Penelitian}

Lokasi yang digunakan penulis dalam penelitian ini, pada Distrik Biak Kota Kabupaten Biak Numfor. 


\section{Populasi dan Sampel}

Populasi adalah wilayah generelasi yang terdiri atas obyek/subjek yang mempunyai kualitas dan karakteristik tertentu yang ditetapkan oleh peneliti untuk dipelajari dan kemudian ditarik kesimpulannya (Sugiyono, 2009: 90). Berdasarkan pengertian tersebut, maka populasi dalam penelitian ini adalah seluruh pegawai Distrik Biak Kota Kabupaten Biak Numfor yang berjumlah 37 orang.

Sampel adalah bagian dari jumlah karakteristik yang dimiliki oleh populasi tersebut (Sugiyono, 2009: 91). Sehubungan dengan hal ini, Winarno (Winarno, 1980: 93) menyatakan pendapatnya sebagai berikut: "Sampel diperlukan bila peneliti tidak bermaksud untuk meneliti seluruh populasi yang ada, karena tidaklah mungkin penelitian secara langsung meneliti segenap populasi, padahal tujuan penelitian adalah menemukan generalisasi secara umum".

Dengan melihat jumlah populasi yang tidak terlalu besar dan bisa dijangkau serta terkonsentrasi pada satu lokasi, maka penelitian ini menggunakan sampel jenuh yakni semua populasi dijadikan sampel yaitu pegawai distrik biak kota yang berjumlah 37 orang.

\section{Teknik Pengumpulan Data}

Dalam penelitian ini, teknik pengumpulan data yang digunakan yaitu: wawancara, observasi dan kuesioner.

\section{Jenis dan Sumber Data}

Sumber data primer adalah sumber pertama di mana sebuah data dihasilkan. Data primer dalam penelitian ini adalah data yang diperoleh secara langsung di lapangan yang bersumber dari hasil angket dan wawancara dengan semua pegawai Distrik Biak Kota Kabupaten Biak Numfor dan masyarakat penerima layanan serta observasi atau pengamatan yang dilakukan langsung untuk mendapatkan data.

Sumber data sekunder adalah sumber data kedua sesudah sumber data primer. Data sekunder dalam penelitian ini adalah data pendukung bagi data primer yang diperoleh dari bahan-bahan literatur seperti dokumen-dokumen serta laporan-laporan dan kepustakaan lainnya yang berhubungan dengan perilaku birokrasi dan kualitas layanan sipil pada Distrik Biak Kota Kabupaten Biak Numfor.

\section{Teknik Analisis Data}

Teknik analisis data yang penulis gunakan dalam penelitian ini adalah teknik analisis deskriptif kualitatif atau analisis presentase menggunakan model Krejick, yang mana penulis mengelompokan hasil dari peranan perilaku birokrasi dan kualitas layanan sipil pada Distrik Biak Kota Kabupaten Biak Numfor:

1. Kategori Sangat Baik

2. Kategori Baik

: $76-100 \%$

3. Kategori Cukup

: $56-75 \%$

4. Kategori Kurang Sekali

: $40-55 \%$

: $\quad<40 \%$ 


\section{KERANGKA TEORETIK DAN KONSEPTUAL}

Momentum Reformasi yang ditandai dengan jatuhnya pemerintah Orde Baru, sebenarnya selain dipicu oleh masalah ekonomi juga merupakan refleksi ketidakpuasan masyarakat terhadap kinerja pemerintah, akibatnya kepercayaan masyarakat terhadap birokrasi pemerintah makin rendah (Edyanto, 2017). Kepemimpinan dibutuhkan manusia karena adanya suatu keterbatasan dan kelebihan-kelebihan tertentu pada manusia. Di satu pihak, manusia terbatas kemampuannya untuk memimpin, di pihak lain ada orang yang mempunyai kelebihan kemampuan untuk memimpin (Karsiman, 2018). Pemerintah sebagai badan yang penting dalam rangka pemerintahannya, pemerintah mesti memperhatikan ketenteraman dan ketertiban umum, tuntutan dan harapan serta pendapat rakyat, kebutuhan dan kepentingan masyarakat, pengaruhpengaruh lingkungan, pengaturan-pengaturan, komunikasi peran serta seluruh lapisan masyarakat dan legitimasi. sebagian dari fungsi utama pemerintahan daerah yang terutama adalah memperbaiki dan menyelesaikan tuntutan/aspirasi masyarakat (Soares, Nurpratiwi, \& Makmur, 2015).

Organisasi dapat dikatakan sukses apabila hubungan komunikasi antar semua pihak internalnya terjalin harmonis (Kurnia Riyantini dan Agus Triyono, 2016). Salah satu yang penting dalam pelayanan masyarakat adalah perilaku birokrasi. Perilaku birokrasi yang berkualitas, yaitu mampu menjamin terpenuhinya kepuasan pelayanan standar kesehatan termasuk secara operasional dapat dilihat pada berbagai kegiatan pelayanan yang bersentuhan langsung dengan publik (Onno Sahlania Hamzah, 2014). Pentingnya perilaku birokrasi dalam organisasi sebagai penentu aktivitas pelayanan untuk mencapai tujuan organisasi, maka segala tindakan yang berorientasi pada pencapaian tujuan harus sesuai dengan perilaku birokrasi (Onno Sahlania Hamzah, 2014). Dalam birokrasi pemerintahan khususnya dalam pelayanan publik, dimensi manusia perlu mendapat perhatian yang serius. Penempatan kembali faktor manusia dalam organisasi adalah menjadi penting, dimana manusia dijadikan sebagai dimensi penentu utama keberhasilan sebuah organisasi termasuk di dalamnya birokrasi pelayanan publik, selain dimensi lainnya yakni dimensi teknis dan dimensi konsep (Hasniati, 2013)

Setiap individu mempunyai karakteristik yang berbeda. Mereka mempunyai nilai, kepercayaan, motivasi, dan kemampuan yang berbeda. Perbedaan tersebut menyebabkan perbedaan perilaku mereka. Namun demikian ikatan utama yang menyatukan perilaku mereka adalah tujuan organisasi. Hal ini penting mengingat perilaku mengarah kepada tujuan organisasi. Organisasi birokrasi sebagai wadah untuk mencapai tujuan pelayanan dan perlindungan masyarakat mempunyai karakteristik adanya hirarki, tugas, wewenang, tanggungjawab, sistem reward, dan sistem kontrol (Thoha dalam Serfianus, Achmad Djumlani, 2014).

\section{HASIL DAN PEMBAHASAN}

Peranan Kepemimpinan dalam Meningkatkan Kualitas Pelayanan Publik pada Distrik Biak Kota Kabupaten Biak Numfor.

Manajemen 
Pada tingkat distrik adalah peranan dari kepala distrik untuk mengatur, menata dan mengarahkan setiap pegawai yang ada untuk dapat melaksanakan semua tugas dan tanggung jawabnya secara baik dalam memberikan pelayanan yang baik dan berkualitas kepada masyarakat yang tinggal di wilayah distrik. Berdasarkan hal tersebut dan ntuk mengetahui peranan kepala distrik dalam meningkatkan kualitas pelayanan kepada masyarakat, telah disebarkan daftar pertanyaan kepada responden yakni pegawai yang menjadi sampel dalam penelitian ini. Adapun hasilnya adalah sebagai berikut:

Tabel 1. Tanggapan Responden Terhadap Peranan Manajemen Kepala Distrik

\begin{tabular}{|c|l|c|c|}
\hline No. & Kategori & Frekuensi & Dalam Persen (\%) \\
\hline 1 & Sangat Baik & 8 & $\mathbf{1 8 , 0 6}$ \\
2 & Baik & 18 & 41,86 \\
3 & Cukup & 11 & $\mathbf{2 5 , 5 8}$ \\
4 & Kurang Baik & 6 & 13,95 \\
\hline & Jumlah & 43 & 100 \\
\hline
\end{tabular}

Sumber: Data Primer Diolah 2019

Dari tabel di atas menunjukan bahwa sebanyak 8 responden atau sebesar 18,o6\% menyatakan bahwa peranan kepala distrik dalam meningkatkan kualitas pelayanan kepada masyarakat melalui manjemen sudah sangat baik, 18 responden atau sebesar 41,86 \% menyatakan baik, 11 responden atau sebesar 25,58 \% menyatakan cukup baik , dan 6 responden atau sebesar 13,95\% menyatakan kurang baik. Dengan demikian dari hasil tanggapan responden dan besaran presentasenya diketahui sebagian besar responden menyatakan bahwa peranan kepala distrik dalam meningkatkan kualitas pelayanan kepada masyarakat melalui manjemen sudah baik.

\section{Penegakan Disiplin}

Disiplin merupakan wujud ketaatan setiap individu yang ada dalam organisasi kepada semua aturan yang berlaku dalam organisasi tersebut. Berbagai aktivitas yang dilakukan oleh anggota organisasi dalam mencapai tujuan akan sangat ditentukan oleh ketaatan mereka dalam mematuhi setiap rencana yang telah ditentukan untuk mencapai tujuan organisasi. Tanpa disiplin yang baik, maka akan sulit bagi anggota organisasi untuk melaksanakan semua tugas dan tanggungjawab yang diberikan oleh organisasi secara baik.

Berdasarkan hal tersebut dan untuk mengetahui peranan kepala distrik dalam meningkatkan penegakan disiplin, telah disebarkan daftar pertanyaan kepada responden yakni pegawai yang menjadi sampel dalam penelitian ini. Adapun hasilnya adalah sebagai berikut: 
Tabel 2.Tanggapan Responden Terhadap Peranan Kepala Distrik dalam Meningkatkan Disiplin

\begin{tabular}{|c|l|c|c|}
\hline No & Kategori & Frekuensi & Dalam Persen (\%) \\
\hline 1 & Sangat Baik & 7 & 16,27 \\
2 & Baik & 20 & 46,51 \\
3 & Cukup & 12 & 27,90 \\
4 & Kurang Baik & 4 & 9,30 \\
\hline \multicolumn{2}{|c|}{ Jumlah } & 43 & 100 \\
\hline
\end{tabular}

Sumber: Data Primer Diolah 2019

Dari tabel di atas menunjukan bahwa sebanyak 7 responden atau sebesar 16,27\% menyatakan bahwa peranan kepala distrik dalam meningkatkan kualitas pelayanan kepada masyarakat melalui peningkatan disiplin sudah sangat baik, 20 responden atau sebesar 46,51 \% menyatakan baik, 12 responden atau sebesar 27,90 \% menyatakan cukup baik, dan 4 responden atau sebesar 9,30 \% menyatakan kurang baik. Dengan demikian dari hasil tanggapan responden dan besaran presantasenya diketahui sebagian besar responden menyatakan bahwa bahwa peranan kepala distrik dalam meningkatkan kualitas pelayanan kepada masyarakat melalui peningkatan disiplin sudah baik.

Sumber Daya Manusia

Sumber daya manusia merupakan sumber daya utama atau modal utama dalam setiap organisasi. Organisasi manapun baik swasta ataupun pemerintah sudah tentu memerlukan sumber daya manusia untuk menggerakan jalannya roda organisasi. Hal ini tidak bisa dipungkiri bahwa setiap organisasi dalam usaha mencapai tujuannya akan sangat ditentukan oleh keberadaan sumber daya manusia dalam melaksanakan seluruh tugas dan tanggungjawab yang menjadi kewajibannya. Berdasarkan hal tersebut dan untuk mengetahui peranan kepala distrik dalam meningkatkan aktivitas sumber daya manusia atau pegawai, telah disebarkan daftar pertanyaan kepada responden yakni pegawai yang menjadi sampel dalam penelitian ini. Adapun hasilnya adalah sebagai berikut:

Tabel 3. Tanggapan Responden Terhadap Peranan Kepala Distrik dalam Meningkatkan Aktivitas Sumber Daya Manusia

\begin{tabular}{|c|l|c|c|}
\hline No & \multicolumn{1}{|c|}{ Kategori } & Frekuensi & Dalam Persen (\%) \\
\hline 1 & Sangat Baik & 10 & 23,15 \\
2 & Baik & 16 & 37,20 \\
3 & Cukup & 11 & 25,58 \\
4 & Kurang Baik & 6 & 13,95 \\
\hline \multicolumn{2}{|r|}{ Jumlah } & 43 & 100 \\
\hline
\end{tabular}

Sumber: Data Primer Diolah 2019

Dari tabel di atas menunjukan bahwa sebanyak 10 responden atau sebesar 23,15\% menyatakan bahwa peranan kepala distrik dalam meningkatkan kualitas pelayanan 
kepada masyarakat melalui peningkatan aktivitas sumber daya manusia sudah sangat baik, 16 responden atau sebesar 37,20\% menyatakan baik, 11 responden atau sebesar 25,58\% menyatakan cukup baik, dan 6 responden atau sebesar 13,95\% menyatakan kurang baik. Dengan demikian dari hasil tanggapan responden dan besaran presantasenya diketahui sebagian besar responden menyatakan bahwa bahwa peranan kepala distrik dalam meningkatkan kualitas pelayanan kepada masyarakat melalui peningkatan aktivitas sumber daya manusia sudah baik.

Motivasi

Berdasarkan hal tersebut dan untuk mengetahui peranan kepala distrik dalam meningkatkan motivasi pegawai, telah disebarkan daftar pertanyaan kepada responden yakni pegawai yang menjadi sampel dalam penelitian ini. Adapun hasilnya adalah sebagai berikut:

Tabel 4. Tanggapan Responden Terhadap Peranan Kepala Distrik Dalam Meningkatkan Motivasi

\begin{tabular}{|c|l|c|c|}
\hline No & \multicolumn{1}{|c|}{ Kategori } & Frekuensi & Dalam Persen (\%) \\
\hline 1 & Sangat Baik & 9 & 20,93 \\
2 & Baik & 20 & 46,51 \\
3 & Cukup & 9 & 20,93 \\
4 & Kurang Baik & 5 & 11,62 \\
\hline & Jumlah & 43 & 100 \\
\hline
\end{tabular}

Sumber: Data Primer Diolah 2019

Dari tabel di atas menunjukan bahwa sebanyak 9 responden atau sebesar 20,93\% menyatakan bahwa peranan kepala distrik dalam meningkatkan kualitas pelayanan kepada masyarakat melalui peningkatan motivasi sudah sangat baik, 20 responden atau sebesar $46,51 \%$ menyatakan baik, 9 responden atau sebesar 20,93\% menyatakan cukup baik, dan 5 responden atau sebesar 11,62\% menyatakan kurang baik. Dengan demikian dari hasil tanggapan responden dan besaran presantasenya diketahui sebagian besar responden menyatakan bahwa bahwa peranan kepala distrik dalam meningkatkan kualitas pelayanan kepada masyarakat melalui peningkatan motivasi sudah baik.

\section{PENUTUP}

Pelaksanaan fungsi birokrasi pada Distrik Biak Kota Kabupaten Biak Numfor telah dilaksanakan, namun belum dilakukan dengan baik yang berdasarkan tanggapan responden masih dikategorikan cukup. Dari penelitian ini bisa dilihat bahwa fungsi birokrasi dengan indikatornya karakteristik individu dan birokrasi sangat berhubungan dengan kualitas layanan sipil, artinya bahwa bila fungsi birokrasi dengan kedua indikatornya dilaksanakan dengan baik, maka kualitas pelayanan sipil yang diberikan kepada masyarakat juga akan semakin baik. 


\section{REFERENSI}

Benny Kurniawan Putra Sembiring, Heri Kusmanto, U. T. (2016). Perilaku Aparat Birokrasi dalam Pelayanan Elektronik Kartu Tanda Penduduk. Jurnal Administrasi Publik, 6(2), 97-106.

Edyanto. (2017). Integritas Birokrat Garis Depan (Street Level Bureucrats) dalam Pelayanan Kesehatan Gratis di Rumah Sakit Umum Daerah (RSUD) ANDI MAKKASAU Kota Parepare. Jurnal Ilmu Pemerintahan, 2(April).

Hasniati. (2013). Sikap dan Perilaku Birokrasi dalam Pelayanan Publik Ditinjau Dari Perspektif Syariat Islam. Al-Fikr, 17(1), 190-203.

Karsiman, E. (2018). Peran Muhammadiyah Dalam Pemberdayaan Masyarakat Kokoda Di Kota Sorong. Noken, 4(1), 23-33.

Kurnia Riyantini dan Agus Triyono. (2016). Pengaruh Kepuasan Komunikasi Organisasi Terhadap Kinerja Pegawai Di Sekretariat DPRD Kota Singkawang. Informasi, 46(2).

Onno Sahlania Hamzah. (2014). Perilaku Birokrasi Pemerintah Dalam Pelayanan Puskesmas Di Kota Makassar. Jurnal Administrasi Publik, 4(1).

Sartika, D. (2013). Analisis Perilaku Birokrasi Dalam Penyelenggaraan Pelayanan Publik di Kelurahan Lambara Kecamatan Tawaeli. Katalogis, 1(7), 135-146.

Serfianus, Achmad Djumlani, D. P. (2014). Perilaku Birokrasi Dalam Pemberian Pelayanan Publik. Jounrnal Administrative Reform, 2(3), 1705-1718.

Soares, A., Nurpratiwi, R., \& Makmur, M. (2015). Peran Pemerintah Daerah Dalam Pembangunan Daerah. JISIP: Jurnal Ilmu Sosial Dan Ilmu Politik, 4(2), 231-236. 